\title{
Mitigating clinician and community concerns about children's flatfeet, intoed gait, or knock-knees
}

\author{
Angela Evans ${ }^{1,2}$ \\ From Australasian Podiatry Conference 2015 \\ Queensland, Australia. 6-8 May 2015
}

\section{Background}

Foot and lower limb postures are a common parental concern, and present frequently to a range of clinicians. Referral of children with flatfeet, intoed gait, or knockknees that is within normal developmental limits has been reported as approximating $40 \%$. This represents a substantial and unnecessary cost to any health care system. The dilemma for caring clinicians is that each of these common presentations can be frankly pathological, so erring on the side of caution is understandable.

\section{Process}

Review of current research for the evidence for treatment of each of flatfeet, intoed gait, or knock-knees/ bow-legs, focussed on diagnosis. Intention was to reduce overuse of both referred (specialist) consultations and unnecessary intervention.

\section{Findings}

It would appear that many clinicians are unsure as to the bounds of what is physiologically normal in terms of foot posture, gait angles, and knee position in childhood. The issue of intervention for paediatric flatfoot is repeatedly reported as being controversial. This need not be, given the direction from evidence and clinical guidelines. Gait angle of progression, and especially intoed gait, is a common concern for which there are known developmental patterns, and scant evidence for intervention. Knee position has a consistently documented progress with age, which generally guides the need for management.

\footnotetext{
Correspondence: angela.evans@latrobe.edu.au

'Department of Podiatry, La Trobe University, Bundoora, Victoria, 3086,

Australia
}

Full list of author information is available at the end of the article

\section{Conclusions}

A framework for clinicians provides three quick questions that can clarify the need to attribute concern for each of these paediatric musculoskeletal conditions, and a diagnostic directive that will reduce the chance of overlooking something more serious - the 3qq.

\section{Authors' details}

'Department of Podiatry, La Trobe University, Bundoora, Victoria, 3086, Australia. ${ }^{2}$ Marion Podiatry, Oaklands Park, Adelaide, South Australia, 5046, Australia.

Published: 22 September 2015

\section{doi:10.1186/1757-1146-8-S2-013}

Cite this article as: Evans: Mitigating clinician and community concerns about children's flatfeet, intoed gait, or knock-knees. Journal of Foot and Ankle Research 2015 8(Suppl 2):013.
Submit your next manuscript to BioMed Central and take full advantage of:

- Convenient online submission

- Thorough peer review

- No space constraints or color figure charges

- Immediate publication on acceptance

- Inclusion in PubMed, CAS, Scopus and Google Scholar

- Research which is freely available for redistribution
() Biomed Central 